\title{
EVALUATION OF SERUM $\gamma$-GLUTAMYL TRANSFERASE AND ITS ASSOCIATION WITH HIGH SENSITIVITY C-REACTIVE PROTEIN AND INSULIN LEVELS IN THE PATIENTS WITH METABOLIC SYNDROME
}

\author{
R. Dharuni1*, B.V. Maruthi Prasad2 ${ }^{2}$, H.L. Vishwanth ${ }^{2}$ \\ 1 - SAPTHAGIRI INSTITUTE OF MEDICAL SCIENCES AND RESEARCH CENTRE, BANGALORE, INDIA \\ 2 - BANGALORE MEDICAL COLLEGE AND RESEARCH INSTITUTE, BANGALORE, INDIA
}

Background. Metabolic syndrome (MS), a collection of cardiovascular risk factors, is a major worldwide public health problem. The gathered data prove that serum gamma-glutamyl transferase (yGT) activity is a true marker of atherosclerotic cardiovascular disease (CVD) and is of a prognostic importance as well as the highsensitivity C-reactive protein (hs-CRP).

Objectives. In the study, we sought to evaluate serum yGT activity, hs-CRP and insulin resistance in patients with MS.

Methods. The study involved 50 persons with metabolic syndrome and 50 healthy age and sex matched controls. Fasting serum samples of all participants were investigated for $y G T$, hs-CRP, insulin, blood glucose, lipid profile and liver function tests. Anthropometric measurements and BMI were also calculated

Results. In that case 50\% showed significantly high yGT compared to the controls, 30\% proved increased $h \mathrm{~s}$-CRP levels above $>0.5 \mathrm{mmol} / \mathrm{L}$, whereas $94 \%$ of the controls were within the reference range. $74 \%$ of cases revealed the presence of insulin resistance while $32 \%$ of the controls showed insulin resistance. High yGT levels were also observed in that case with deranged lipids levels and high BMI.

Conclusions. The study suggests that the patients with MS have a higher serum yGT activity. This study also proves that hs-CRP and HOMA-IR, which are independent risk factors of CVD, are also associated with MS. The correlation between $y G T$ and the components of MS are also found significant compared to hs-CRP. Thus, YGT can be considered as an inexpensive and authentic predictor of MS, which can be a manifestation of CVD in near future.

Key words: metabolic syndrome; gamma-glutamyl transferase; high sensitivity C-reactive protein; HOMA-IR.

\section{Introduction}

Metabolic syndrome (MS) is defined by a constellation of risk factors of cardiovascular disease (CVD), that include abdominal obesity, dyslipidemia, hypertension, and impaired glucose tolerance, which increase the risk of CVD and diabetes mellitus [1]. MS has been considered as one of the threatening non communicable public-health problem globally [2].

Serum gamma-glutamyl transferase ( $y G T$ ) has long been considered a harbinger of hepatic dysfunction and alcohol intake [3]. Recently, accumulating epidemiology studies have revealed that yGT contributes in several pathophysiological processes, including oxidative stress and lipid peroxidation, which are important for pathogenesis and development of insulin resistance as well as MS $[4,5,6]$. In addition, when compared with other hepatic

*Corresponding author: Dr. R. Dharuni, Department of Biochemistry, Sapthagiri Institute of Medical Sciences \& Research Centre, Hesarghatta Main road, Bangalore, Karnataka, India Phone No.: +91-9535101939

Email: dharunii@gmail.com markers, yGT was the major predictor of type 2 diabetes $[7,8,9]$. yGT is a possible risk factor and a prognostic indicator of CVD. Further information is needed regarding the magnitude of the risk associated with YGT activity and individual cardiometabolic disorders. Such a relationship could help to decipher a high prevalence of MS.

Perhaps excessive energy consumption, which leads to obesity, is a more serious and frequent nutritional problem, but there can be a gradual and fairly predictable transition from simple obesity with no observable metabolic changes through insulin resistance. Insulin resistance arises from the inability of insulin to act normally in regulating nutrient metabolism in peripheral tissues. Increasing evidences of human population studies and animal research have established correlative as well as causative relations between chronic inflammation and insulin resistance [10]. Chronic, systemic, subclinical inflammation has also been identified as a driving force for insulin resistance. Since 
hs-CRP is a marker of systemic inflammation, it might explain the prevalence of insulin resistance in MS. Nevertheless, the relationship remains uncertain and has not been well researched yet. Therefore, the aim of this study was to examine the associations of serum yGT, hs-CRP and insulin resistance in the individuals with MS as well as its components.

\section{Methods}

\section{Source of Data}

This study was a hospital based cross sectional study, which comprised metabolic syndrome patients attending the outpatient and inpatient Departments of Medicine. The study was approved by the Local ethical committee of the institute and the informed consents were obtained from all subjects, who took part in the study.

Selection of Subjects

All subjects were diagnosed according to National Cholesterol Education Program, Adult Treatment Panel III criteria and it required the presence of 3 or more of the following [2]: a) fasting blood glucose $\geq 6.105 \mathrm{mmol} / \mathrm{L}$; b) serum triglyceride $\geq 1.71 \mathrm{mmol} / \mathrm{L}$ or being on lipid lowering therapy; c) Serum HDL < $2.220 \mathrm{mmol} / \mathrm{L}$ in men and $<2.775 \mathrm{mmol} / \mathrm{L}$ in women or being on antilipidemic therapy; d) blood pressure $\geq 130 \mathrm{mmHg}$ systolic and/or $\geq 85 \mathrm{mmHg}$ diastolic or being on antihypertensive therapy; and e) waist circumference $>102 \mathrm{~cm}$ in men and $>88 \mathrm{~cm}$ in women. The subjects with following history were excluded. Alcohol intake more than $30 \mathrm{~g} /$ day ( $\approx 38 \mathrm{ml}$ of $100 \%$ alcohol) and the patients with smoking history, Hepatitis $\mathrm{B}$ or $\mathrm{C}$ infection or other known liver diseases, liver enzymes exceeding the upper reference range in three times, use of hepatotoxic drugs, acute infectious/inflammatory conditions, familial hyperlipidemia, New York Heart Association class 3-4 heart failure.

\section{Sample size}

After consulting a statistician, sample size was estimated to be 100 , with 50 cases and 50 age and sex matched healthy controls. study.

Type of study: a cross sectional observational

\section{Method of sample collection}

The informed consents were taken from the patients and control subjects. The selected subject's blood samples were collected with all aseptic precautions. $5 \mathrm{ml}$ of blood was collected from median cubital vein. The collected blood was allowed to clot for 30 minutes in a clean dry test tube and was subjected to centrifugation to separate the serum. The serum samples were stored in a Deep freezer at $-80^{\circ} \mathrm{C}$ till they were studied.

The following parameters were considered appropriate for the study:

1. Serum insulin levels defined by chemiluminescence method and insulin resistance by homeostasis of model assessment of insulin resistance (HOMA-IR).

2. Serum yGT by colorimetric method.

3. hs-CRP by chemiluminescence method.

4. Renal and liver function tests by colorimetric method.

5. Lipid profile by enzymatic, colorimetric method.

6 . Fasting blood sugar by hexokinase method.

7. Measurement of body mass index.

8. To measure waist circumference, top of right iliac crest was located. A measuring tape was placed in a horizontal plane around abdomen at level of iliac crest. Before reading the measurements, it was estimated that the tape was snug but did not compress the skin and was parallel to floor. The assessment was performed at the end of normal expiration.

Statistical analysis

Descriptive and inferential statistical analysis has been carried out during the study. The results on continuous measurements are presented on Mean \pm SD (Min-Max) and the results on categorical measurements are presented in Number (\%). Statistical processing of the research results was performed by parametric analysis with the calculation of Student's t-test using the software package Microsoft EXCEL 5.0. Chi-square test was used to find the significance of study parameters on categorical scale between two or more groups. Pearson correlation between yGT and HOMA-IR and hsCRP were performed to measure the strength between variables and relationships.

\section{Results}

The clinical characteristics of the study population are presented in Table 1. The current study is a case control study, in which the serum yGT, hs-CRP and insulin levels were determined in 50 metabolic syndrome subjects and were compared with 50 healthy age and sex matched controls. The results were tabulated and statistically analyzed.

The metabolic syndrome patients were diagnosed according to the National Cholesterol Education Program's Adult Treatment Panel III criteria (NCEP ATP III criteria). The study 
Table 1. Clinical characteristics of the study population

\begin{tabular}{|l|c|c|c|}
\hline \multicolumn{1}{|c|}{ Parameters } & Controls & Cases & P value \\
\hline None of the subjects & 50 & 50 & 0.68 \\
\hline Sex $($ male/female) & $18 / 32$ & $20 / 30$ & $<0.05^{*}$ \\
\hline Age & $50.2 \pm 9$ & $51.4 \pm 9.7$ & $<0.001$ ** \\
\hline BMI $\left(\mathrm{kg} / \mathrm{m}^{2}\right)$ & $21.5 \pm 3.5$ & $29.6 \pm 3.9$ & $<0.001$ ** \\
\hline Waist circumference $(\mathrm{cm})$ & $82.5 \pm 10.3$ & $104 \pm 9.5$ & \\
\hline
\end{tabular}

Note: the values expressed as mean \pm SD. t-test was used for groups' comparison.

The differences in proportions were assessed by means of Chi-square test.

* Suggestive significance ( $P$ value $P<0.05)$;

** Strongly significant ( $P$ value $P \leq 0.001)$.

population belonged to age group ranging 4070 years old, which was similar in the controls as well. The mean $\pm S D$ of the cases and controls were $51.4 \pm 9$. 7 years old and $50.2 \pm 9$ years old respectively, which suggested that metabolic syndrome was prevalent in late middle ages. Waist circumference (WC) and body mass index (BMI) are the two important anthropometric measurements among the various definitions of metabolic syndrome. The study proved the mean $\pm S D$ for $W C$ in that case as $104 \pm 9.5 \mathrm{~cm}$ and in the controls as $82.5 \pm 10.3 \mathrm{~cm}$. And the mean BMI in that case was $29.58 \pm 3.96 \mathrm{~kg} / \mathrm{m}^{2}$ and in the controls - $23.14 \pm 2.52 \mathrm{~kg} / \mathrm{m}^{2}$. Both these parameters were significantly higher in the cases with $\mathrm{p} \leq 0.001$.

The biochemical characteristics of the study population are presented in Table 2. The mean concentration of fasting blood glucose in the controls was $4.1 \pm 0.93 \mathrm{mmol} / \mathrm{L}$; in that case it was $6.5 \pm 2.1 \mathrm{mmol} / \mathrm{L}$, which was significantly increased in the subjects with MS. Increased triacylglycerols and decreased HDL-cholesterol were potential markers of CVD.
In this study, mean Triglycerides in metabolic syndrome cases was $1.86 \pm 0.96 \mathrm{mmol} / \mathrm{L}$ and in the controls, it was $1.41 \pm 0.8 \mathrm{mmol} / \mathrm{L}$, which was significantly higher. HDL-cholesterol levels in cases were found to be $0.73 \pm 0.2 \mathrm{mmol} / \mathrm{L}$ and $0.96 \pm 0.3 \mathrm{mmol} / \mathrm{L}$ in the controls. The lower HDLcholesterol levels in that case was found to be significant with $p<0.005$.

The mean \pm SD of $y G T$ in that case was $60.96 \pm 45.64 \mathrm{U} / \mathrm{L}$ and in the controls $29.78 \pm 18.01 \mathrm{U} / \mathrm{L}$ with a $\mathrm{P}$ value $<0.001 * *$. The mean $\pm S D$ of serum insulin in that case was $29.34 \pm 26.94 \mu \mathrm{IU} / \mathrm{ml}$ and in the controls $11.97 \pm 5.98 \mu \mathrm{IU} / \mathrm{ml}$ with $\mathrm{P}$ value $\leq 0.01 * *$. The mean $\pm S D$ of hs-CRP in that case was $76.2 \pm 47.6$ $\mathrm{mmol} / \mathrm{L}$ and in the controls $27.6 \pm 11.4 \mathrm{mmol} / \mathrm{L}$ with $\mathrm{P}$ value $\leq 0.001 * *$. The mean \pm SD of HOMAIR in that case was $9.44 \pm 4.39$ and in the controls $2.32 \pm 1.48$ with $P$ value $\leq 0.001 *$ *

The comparison of yGT, insulin, hs-CRP, HOMA-IR is presented in Table 3. Pearson correlation was completed to analyse the relationship between yGT, hs-CRP and HOMA-IR in MS cases are as presented in Table 4. yGT

Table 2. Biochemical characteristics of the study population

\begin{tabular}{|l|c|c|c|}
\hline \multicolumn{1}{|c|}{ Variables } & Controls & Cases & P value \\
\hline Glucose $(\mathrm{mmol} / \mathrm{L})$ & $4.1 \pm 0.93$ & $6.5 \pm 2.1$ & $<0.01^{*}$ \\
\hline Total cholesterol $(\mathrm{mmol} / \mathrm{L})$ & $3.8 \pm 1.16$ & $4.3 \pm 1.38$ & $<0.05^{*}$ \\
\hline Triglycerides $(\mathrm{mmol} / \mathrm{L})$ & $1.41 \pm 0.8$ & $1.86 \pm 0.96$ & $<0.05^{*}$ \\
\hline HDL cholesterol $(\mathrm{mmol} / \mathrm{L})$ & $0.96 \pm 0.3$ & $0.73 \pm 0.2$ & $<0.05^{*}$ \\
\hline Serum albumin $(\mathrm{mmol} / \mathrm{L})$ & $36.7 \pm 8.2$ & $31.8 \pm 7.4$ & $<0.01^{*}$ \\
\hline Aspartate aminotransferase (U/L) & $19.8 \pm 7.9$ & $24.26 \pm 15$ & 0.06 \\
\hline Alanine aminotransferase (U/L) & $17 \pm 9.7$ & $22.38 \pm 12.1$ & $<0.01^{* *}$ \\
\hline Alkaline phosphatase $(\mathrm{U} / \mathrm{L})$ & $71.4 \pm 25.6$ & $83.5 \pm 33.9$ & $<0.05^{*}$ \\
\hline Serum phosphate $(\mathrm{mmol} / \mathrm{L})$ & $1.1 \pm 0.2$ & $0.9 \pm 0.2$ & $<0.01^{* *}$ \\
\hline Serum creatinine $(\mu \mathrm{mol} / \mathrm{L})$ & $61.9 \pm 26.5$ & $53.5 \pm 0.3$ & $<0.01^{* *}$ \\
\hline
\end{tabular}

Notes: the values expressed as mean SD. T-test was used for groups comparison.

* Suggestive significance ( $P$ value $<0.05$ );

* Moderately significant ( $P$ value $<0.01$ );

** Strongly significant ( $P$ value $\leq 0.001)$. 
Table 3. Comparison of y-GT, insulin, hs-CRP, HOMA-IR in both study groups

\begin{tabular}{|l|c|c|c|}
\hline Parameters & Controls & Cases & P value \\
\hline $\mathrm{y}-\mathrm{GT}(\mathrm{U} / \mathrm{L})$ & $29.78 \pm 18.01$ & $60.96 \pm 45.64$ & $<0.001$ ** \\
\hline Insulin $(\mu \mathrm{IU} / \mathrm{ml})$ & $11.97 \pm 5.98$ & $29.34 \pm 26.94$ & $<0.01$ * \\
\hline hs-CRP $(\mathrm{mmol} / \mathrm{L})$ & $27.6 \pm 11.4$ & $76.2 \pm 47.6$ & $<0.001$ ** \\
\hline HOMA-IR & $2.32 \pm 1.48$ & $9.44 \pm 4.39$ & $<0.01 *$ \\
\hline
\end{tabular}

Notes: values expressed as mean \pm SD.

Z-test was used for groups comparison *. Suggestive significance ( $P$ value $<0.05$ ).

* Moderately significant ( $P$ value $<0.01$ );

** Strongly significant ( $P$ value $\leq 0.001)$.

Table 4. Pearson correlation of y-GT, HOMA-IR, hs-CRP in metabolic syndrome

\begin{tabular}{|l|c|c|}
\hline \multirow{2}{*}{ Parameters } & \multicolumn{2}{|c|}{$\begin{array}{c}\text { Metabolic syndrome } \\
\text { (n=50) }\end{array}$} \\
\cline { 2 - 3 } & rvalue & P value \\
\hline yGT vs HOMA-IR & 0.26 & $0.060+$ \\
\hline yGT vs hs-CRP & 0.252 & $0.078+$ \\
\hline hs-CRP vs HOMA-IR & 0.207 & 0.15 \\
\hline
\end{tabular}

Notes: + suggestive significance.

showed a positive correlation with HOMA IR and hs-CRP which was of suggestive significance.

\section{Discussion}

MS comprises a group of atherogenic factors [11]. Besides, the gathered data have reported of many biochemical and anthropometric parameters associated with MS, together with parameters of obesity and products released by adipose tissue, plasma insulin levels, liver enzymes, and CRP $[12,13]$.

Many epidemiology studies have proved that circulating serum yGT levels may be associated with the evolvement and clinical progression of CVD, even after adjusting for confounding factor like alcohol consumption $[14,15]$. Although high levels of $y G T$ have been speculated to be directly atherogenic [16], just like several other biomarkers for MS, a direct causation of atherosclerosis remains to be elucidated. As presented in Table 3, a higher yGT along with insulin resistance levels in MS involves a potentially greater risk for subsequent development of type 2 diabetes.

The increasing evidences have proved that the circulating yGT, which is primarily synthesized from liver, is a key target organ for development of MS. A number of studies have also shown that the serum level of yGT directly correlates with an increased risk of MS [17]. This was evidenced by significant correlations between yGT levels and all MetS components, independently of age and gender, except for blood pressure values [18]. Hardly any studies have proved increased yGT activity in hypertensives, which could be associated with the relation between yGT and MS $[19,20]$.

The association between the serum yGT and hs-CRP (Table 2), which is, as put forward by Ortega et al. [21], the low-grade inflammation in liver caused by hepatic steatosis in MS, could have caused increase in yGT levels. hs-CRP, an acute-phase reactant of hepatic origin and a sensitive marker for systemic inflammation, predicts the occurrence of diabetes, metabolic syndrome and atherosclerotic diseases in healthy subjects [23]. It has been hypothesized that increased yGT levels might occur before elevation in CRP, and the related oxidative stress would give rise to a subsequent inflam matory response [24]. Also, fatty infiltration in liver might have enhanced oxidative stress, leading to glutathione metabolism with com pensatory increase in yGT secretion. As yGT activity reflects oxidative stress and inflammation, the increased levels can actively predict the incidence of MS [17].

Many studies have proved the association between the increased yGT and insulin resistance, as well as the subsequent development of type 2 DM $[14,19]$. The increase of yGT levels in serum might be as a result of secondary hepatic inflammation [22].

\section{Conclusions}

This study suggests that increased gammaglutamyl transferase activity could be considered as harbinger of low-grade systematic 
inflammation and oxidative stress through mediation of glutathione transport. Current study contributes to the increasing number of evidences that gamma-glutamyl transferase estimation in metabolic syndrome, which is simple and inexpensive, could be considered among the strongest serum predictors of insulin resistance, imminent type 2 diabetes and cardiovascular events.

Conflict of interest

The authors declare no conflict of interest.

\title{
ВЗАЄМОЗВ'ЯЗОК МІЖ ПОКАЗНИКАМИ ГАММА-ГЛЮТАМІЛТРАСФЕРАЗИ, ВИСОКОЧУТЛИВОГО С-РЕАКТИВНОГО БІЛКА ТА РІВНЯ ІНСУЛІНУ У ПАЦІЄНТІВ 3 МЕТАБОЛІЧНИМ СИНДРОМОМ
}

\author{
R. Dharuni ${ }^{1}$, B.V. Maruthi Prasad ${ }^{2}$, H.L. Vishwanth ${ }^{2}$ \\ 1 - SAPTHAGIRI INSTITUTE OF MEDICAL SCIENCES AND RESEARCH CENTRE, BANGALORE, INDIA \\ 2 - BANGALORE MEDICAL COLLEGE AND RESEARCH INSTITUTE, BANGALORE, INDIA
}

Вступ. Метаболічний синдром (MC), як сукупність факторів ризику розвитку серцево-судинних захворювань (ССЗ), є важливою проблемою охорони здоров'я. Отримані дані свідчать про те, що активність сироваткової гамма-глютамілтрансферази (ГГТ), у якості маркера атеросклеротичного процесу при ССЗ, має прогностичне значення, як і показники високочутливого С-реактивного білка (вчСРБ).

Мета. Дослідити активність сироваткової ГГТ, вч-СРБ та інсулінорезистентність у пацієнтів з метаболічним синдромом.

Методи. Дослідження включало 50 пацієнтів з МС та 50 здорових осіб. Зразки сироватки були взяті у всіх учасників натщесерче для дослідення активності ГГТ, рівня вч-СРБ, інсуліну, глюкози в крові, оцінки ліпідного профілю та проведення печінкових проб. Також були розраховані антропометричні показники та індекс маси тіла (IMT).

Результати. У 50\% досліджваних з метаболічним синдромом активність ГГТ була достовірно вищою відносно контрольної групи, у 30\% діагностовано підвищений рівень вч-СРБ (вище >0,5 ммоль/л), тоді як показники 94\% осіб контрольної групи знаходилися в діапазоні норми. У 74\% випадків виявлено наявність інсулінорезистентності у пацієнтів з метаболічним синдромом, тоді яку контрольній групі цей показник склав 32\%. Висока активність ГГТ також спостерігалася при порушеннях ліпідного профілю та високому IMT.

Висновок. Отримані нами дані свідчать, що у пацієнтів з метаболічним синдромом активність сироваткової гамма-глютамілтрансферази достовірно вища, порівняно з контрольною групою. Також нами встановлено, що показники високочутливого С-реактивного білка та рівень інсулінорезистентності, які є незалежними факторами ризику серцево-судинних захворювань, також асоціюються з метаболічним синдромом. Встановлено кореляційні зв'язки між активністю гамма-глютамілтрансферази та високочутливого С-реактивного білка.

Таким чином, показники сироваткової гамма-глютамілтрансферази можна розглядати як економічно доступний та достовірний предиктор метаболічного синдрому, що може передувати появі серцево-судинних захворювань у найближчому майбутньому.

КЛЮЧОВІ СЛОВА: метаболічний синдром; гамма-глютамілтрансфераза; високочутливий C-реактивний білок; індекс HOMA-IR (Homeostasis Model Assessment of Insulin Resistance).

Information about authors

R. Dharuni - Assistant Professor, Department of Biochemistry, Sapthagiri Institute of Medical Sciences and Research Centre, Bangalore, Karnataka, India.

ORCID 0000-0002-3543-2810, e-mail: dharunii@gmail.com

B.V. Maruthi Prasad - Professor, Bangalore Medical College and Research Institute, Bangalore, Karnataka, India.

ORCID 0000-0002-2951-9151, e-mail: maruthiprasadbv@gmail.com

H.L. Vishwanth - Professor and Head, Bangalore Medical College and Research Institute,

Bangalore, Karnataka, India.

ORCID 0000-0001-7331-4308, e-mail: drvishwanathhl@gmail.com 


\section{References}

1. Alberti KG, Eckel RH, Grundy SM, Zimmet PZ, Cleeman JI, Donato KA, et al. Harmonizing the metabolic syndrome: $A$ joint interim statement of the international diabetes federation task force on epidemiology and prevention; national heart, lung, and blood institute; American heart association; world heart federation; International atherosclerosis society; and international association for the study of obesity. Circulation. 2009;120:1640-5.

doi: 10.1161/CIRCULATIONAHA.109.192644

2. Mottillo S, Filion KB, Genest J, Joseph L, Pilote L, Poirier $P$, et al. The metabolic syndrome and cardiovascular risk a systematic review and metaanalysis. J Am Coll Cardiol. 2010;56:1113-32.

doi: 10.1016/j.jacc.2010.05.034

3. Nemesánszky E, Lott JA. Gamma-glutamyltransferase and its isoenzymes: Progress and problems. Clin Chem. 1985;31:797-803.

https://www.ncbi.nlm.nih.gov/pubmed/2859933

4. André $P$, Balkau $B$, Vol $S$, Charles MA, Eschwège E, DESIR Study Group, et al. Gamma-glutamyltransferase activity and development of the meta bolic syndrome (International diabetes federation definition) in middle-aged men and women: Data from the epidemiological study on the insulin resistance syndrome (DESIR) cohort. Diabetes Care. 2007;30:2355-61.

doi: $10.2337 / \mathrm{dc} 07-0440$

5. Targher G. Elevated serum gamma-glutamyltransferase activity is associated with increased risk of mortality, incident type 2 diabetes, cardiovascular events, chronic kidney disease and cancer A narrative review. Clin Chem Lab Med. 2010;48:14757.

doi: 10.1515/CCLM.2010.031

6. Turgut O, Tandogan I. Gamma-glutamyltransferase to determine cardiovascular risk: Shifting the paradigm forward. J Atheroscler Thromb. 2011;18:177-81.

doi: $10.5551 /$ jat.6189

7. Cho NH, Jang HC, Choi SH, Kim HR, Lee HK, Chan JC, et al. Abnormal liver function test predicts type 2 diabetes: A community-based prospective study. Diabetes Care. 2007;30:2566-8.

doi: $10.2337 /$ dc07-0106

8. Ford ES, Schulze MB, Bergmann MM, Thamer C, Joost HG, Boeing $H$, et al. Liver enzymes and incident diabetes: Findings from the European prospective investigation into cancer and nutrition (EPIC)potsdam study. Diabetes Care. 2008;31:1138-43.

doi: $10.2337 /$ dc07-2159

9. Sato KK, Hayashi T, Nakamura Y, Harita N, Yoneda T, Endo G, et al. Liver enzymes compared with alcohol consumption in predicting the risk of type 2 diabetes: The Kansai healthcare study. Diabetes Care. 2008;31:1230-6.

doi: $10.2337 / \mathrm{dc} 07-2184$

10. Xu H, Barnes GT, Yang Q, et al. Chronic inflammation in fat plays a crucial role in the development of obesity-related insulin resistance. J Clin Invest 2003; 112: 1821-30. doi: 10.1172/JCI200319451
11. Grundy SM, Cleeman JI, Daniels SR, Donato $\mathrm{KA}$, Eckel RH, Franklin BA, et al. Diagnosis and management of the metabolic syndrome: An American heart association/National heart, lung, and blood institute scientific statement: Executive summary. Crit Pathw Cardiol. 2005;4:198-203

doi: 10.1097/00132577-200512000-00018

12. Tracy RP. Inflammation, the metabolic syndrome and cardiovascular risk. Int J Clin Pract Suppl. 2003;134:10-7.

https://www.ncbi.nlm.nih.gov/pubmed/12793593

13. González AS, Guerrero DB, Soto MB, Díaz SP, Martinez-Olmos M, Vidal O, et al. Metabolic syndrome, insulin resistance and the inflammation markers C-reactive protein and ferritin. Eur J Clin Nutr. 2006;60:802-9.

doi: 10.1038/sj.ejcn.1602384

14. Wei D, Chen T, Gao Y, Tian H. Serum gamma-glutamyltransferase and ferritin are related to insulin resistance: A Populationbased study. Clin Lab. 2015;61:1157-61.

doi: 10.7754/Clin.Lab.2015.150227

15. Emdin M, Passino C, Michelassi C, Donato L, Pompella A, Paolicchi A, et al. Additive prognostic value of gamma-glutamyltransferase in coronary artery disease. Int J Cardiol. 2009;136:80-5.

doi: 10.1016/j.ijcard.2008.04.030

16. Du G, Song Z, Zhang Q. Gamma-glutamyltransferase is associated with cardiovascular and all-cause mortality: A meta-analysis of prospective cohort studies. Prev Med. 2013;57:31-7.

doi: 10.1016/j.ypmed.2013. 03.011

17. Kunutsor SK, Apekey TA, Seddoh D. Gamma glutamyltransferase and metabolic syndrome risk: A systematic review and doseresponse meta-analysis. Int J Clin Pract. 2015;69:136-44.

doi: $10.1111 /$ ijcp. 12507

18. Relationship between serum gammaglutamyltransferase activity and cardiometabolic risk factors in metabolic syndrome. J Family Med Prim Care. 2018;7(2):430-434.

doi: 10.4103/jfmpc.jfmpc_194_17

19. Liu CF, Gu YT, Wañg HY, Fang NY. Gamma-glutamyltransferase level and risk of hypertension: A systematic review and metaanalysis. PLoS One. 2012;7:e48878

doi: 10.1371/journal.pone .0048878

20. Stranges S, Trevisan M, Dorn JM, Dmochowski J, Donahue RP. Body fat distribution, liver enzymes, and risk of hypertension: Evidence from the western New York study. Hypertension. 2005;46:1186-93.

doi: 10.1161/01.HYP.0000185688.81320.4d 
21. Ortega E, Koska J, Salbe AD, Tataranni PA, Bunt JC. Related articles, links serum gamma-glutamyl transpeptidase is a determinant of insulin resistance independently of adiposity in Pima Indian children. J Clin Endocrinol Metab 2006;91:1419-22.

doi: 10.1210/jc.2005-1783

22. Aksakal E, Tanboga IH, Kurt M, Kaygın MA, Kaya A, Isik T, et al. The relation of serum gamma-glutamyl transferase levels with coronary lesion complexity and long-term outcome in patients with stable coronary artery disease. Atherosclerosis 2012;221:596-601

doi: 10.1016/j.atherosclerosis.2012.01.044
23. Ridker PM, Wilson PW, Grundy SM. Should C-reactive protein be added to metabolic syndrome and to assessment of global cardiovascular risk? Circulation 2004; 109: 2818-2825. doi: 10.1161/01.CIR.0000132467.45278.59

24. Lee DH, Jacobs DR Jr. Association between serum gammaglutamyltransferase and C-reactive protein. Atherosclerosis 2005; 178: 327-330.

doi: 10.1016/j.atherosclerosis.2004.08.027

Received 16 December 2018; revised 04 January 2019; rerevised 14 March 2019; accepted 25 April 2019.

This is an open access article distributed under the Creative Commons Attribution License, which permits unrestricted use, distribution, and reproduction in any medium, provided the original work is properly cited. 